\section{African Meteorological Workers}

Training of Africans in the Meteorological Department in Kenya was started some years ago and increasing numbers are now joining the Service. Most of the workers have been educated at African schools and have passed the Junior Secondary School Examination. An entrance examination to the Department ensures that the candidates have a reasonably sound knowledge of arithmetic, English, physics and geography. Sections of the Service include observing, clerical climatological work and printing. Africans trained for the Observing Section are liable to be sent anywhere in Kenya and a few have gone as far as Uganda and Tanganyika Territory. A course beforehand of a few months duration enables these men to read instruments such as thermometers and barometers. They learn to distinguish between the different types of clouds and to report weather visibility and wind force and direction. Training is also given in pilot balloon observations, and Africans have shown remarkable adaptability in this difficult task. The Climatological Section covers a wide field and here also Africans are not lacking in ability. Printing is a task to which the African takes readily, and all reports, summaries and rainfall bulletins are printed on the premises, as well as all the necessary forms for the Department. Rates of pay and facilities for leave are the same as for other Government Departments. Hours are also similar, except for the observers, whose duties must necessarily be irregular.

\section{Integration of Research in the United States}

Dr. R. H. Heindel, director of the American Library of the Office of War Information, has contributed to the May issue of Agenda an article "The War and Post-War Integration of Research Activities in the United States", which is of considerable general interest to scientific workers. The article gives a comprehensive picture of the extensive development of decentralized research in the United States, especially in science, to implement the war research programme, and should be read in conjunction with Dr. Karl T. Compton's Pilgrim Trust Lecture (NATURE, May 29, p. 601). The integration of Federal and non-Federal research facilities is a war problem of the highest importance in view of the limited number of specialists and the need for protecting the nation's research structure, now and in post-war reconstruction. The Federal Government has for many years been developing, with all kinds of re. sponsible research agencies, patterns of procedure and co-operation which have proved useful during the War and should not be without value in considering the organization of research in Great Britain and in the British Commonwealth, and particularly the relations between Government researchinstitutions and the universities. The types of investigation suitable for 'farming out' or contracting are almost unlimited. Contracting for research and co-operative programmes depend on the existing personnel, the fields of study, the nature of the problems, the structure of the official and private agencies and the community of agencies willing to serve the nation as a whole, and success here requires more coherence and direction in the formulated needs of the Government. Government demands for certain types of research may encourage within the universities and elsewhere a greater use of inter-departmental and inter-disciplinary approaches to research projects.
In regard to detail, Dr. Heindel refers to an impressive programme of research development and the most extensive use of contracting with substantial funds, centring about the Office of Scientific Research and Development, within the Office for Emergency Management, to which are attached an Advisory Council, the National Defence Research Committee and the Committee on Medical Research. One of the most successful contracts exists between the Public Roads Administration and the National Resiarch Council for the Highway Research Board, while the U.S. Office of Education has also stimulated and participated in numerous co-operative research projects with State and private agencies. The Bureau of Foreign and Domestic Commerce has been extending its co-operation with university schools of business and departments of economics, and acts as a clearing house for business and economic research. Moreover, in the use it makes of the results of scientific study in its legislative duties and in its responsibility as the appropriating authority for the Federal research programme, Congress occupies an important place in the research structure of the nation. In this article, Dr. Heindel's map of research in the United States is not always as clear as it might be, but he indicates the right questions to which answers must be forthcoming if the machinery for co-ordination, for co-operation and contracting is to be used with success and the results of research conveyed to the proper people.

\section{"Abstracts from Cancer Research"}

THE problems of the nature and possible treatment of malignant disease are studied in many laboratories and results are published in different journals. It is difficult for any worker to keep in touch with all the published work. Excellent summaries of papers were published for many years in the Cancer Review, the publication of which was unfortunately suspended about ten years ago. Since then abstracts have been available in the American Journal of Cancer, which has now been replaced by Cancer Research. The "Abstracts from Cancer Research" are published separately and the first volume covers the year 1941. The summaries are grouped under the main headings of experimental research (including carcinogenic compounds, hormones, viruses, genetics, physical factors, radiation, chemosurgery, biochemistry and nutrition-chemotherapy, immunology, leukæmia, transplantation and tissue culture), comparative oncology, clinical and pathological reports, statistics and cancer control and public health. The production seems admirable and should be of great value to cancer research workers. This new journal is published in America by the International Cancer Research Foundation, but Prof. E. L. Kennaway and Dr. W. E. Gye arrange for the abstracting of articles appearing in publications in the British Commonwealth.

\section{Laryngology and Folk-lore}

IN a recent paper ( $J$. Laryng. and Otol., 57, 527 ; 1942 ) on this subject, Dr. J. D. Rolleston states that up to the time of Morgagni (1682-1771), who described several cases in which it was diseased, the larynx occupied a very subordinate place in pathology, its existence being almost ignored by ordinary students of medicine. On the other hand, there are several references in classical antiquity to popular miethods of dealing with diseases of the throat, as 
can be seen by references to them in Celsus, Pliny, Marcellus Empiricus and Julius Modestus. In the Middle Ages a combination of folk-lore with orthodox practice is illustrated by the fact that Aetius of Amida (fourth century A.D.) recommended that after other methods had failed to remove a foreign body from the throat it should be invoked in the name of St. Blaise, the patron saint for diseases of this kind, "to come up or go down". In the eighteenth century, numerous popular terms, especially in Scotland, were given to a special form of laryngitis occurring in children, such as 'croup', 'croops', 'chock', 'stuffing' or 'rising of the lights'. As in the case of many other diseases and morbid conditions, folk-lore has only a few prophylactic measures compared with curative treatment, while its therapy can be grouped under animal remedies, plant remedies, patron saints and miscellaneous remedies.

\section{Earthquakes Registered in New Zealand}

DURING April 1943, eleven strong distant earthquakes were registered by the seismographs at Auckland, Arapuni, Christchurch, Kaimati, New Plymouth, Tuai and Wellington, New Zealand. The earthquake of April 6 registered at most of the New Zealand stations occurred at $16 \mathrm{~h} .07 \cdot 1 \mathrm{~m}$. U.T. near latitude $32^{\circ} \mathrm{S}$., longitude $70^{\circ} \mathrm{W}$., according to the U.S. Coast and Geodetic Survey. This is mid-way between Illapel and Mendoza in Chile. The earthquake also registered at College, St. Louis, Ottawa, Sitka, Georgetown and fourteen other stations sending records to Washington. The earthquake of April 9 occurred at about $8 \mathrm{~h} .48 \cdot 8 \mathrm{~m}$. U.T. from an epicentre as determined by the U.S. Coast and Geodetic Survey near latitude $19^{\circ} \mathrm{N}$., longitude $145^{\circ} \mathrm{E}$., which is in the Pacific Ocean west of Agrigan Island, one of the Marianas Islands. In this case the depth of focus was near $100 \mathrm{~km}$. Additionally, twenty-nine local earthquakes and earth tremors were recorded. Five of these shocks reached intensity $V$ on the modified Mercalli scale. The first, on April 6, was felt in the Wairoa region; the second, also on April 6, was felt near Hawkes Bay; the third, on April 7, was also felt near Hawkes Bay; the fourth, on April 15, was felt over the southern part of North Island, while the fifth, also on April 15, was felt at Manawatu and Wairarapa.

\section{Food Situation in Sweden}

According to the Anglo-Swedish Review of July, comparison of Sweden's rations with those of foreign countries seems to show that the Swedish rations are surprisingly small. Three important products, how ever, namely, milk, potatoes and other vegetables, are not rationed but can be bought in unlimited quantities. Temporary visitors to Sweden who eat their meals at restaurants may think the food situation is more favourable than it really is. In a restaurant coupons are only required for butter, bread, most of the meat products and eggs. On the other hand, for Swedish households the coupon-free meat products play a very minor part, and their price is so high that they are almost beyond the reach of most consumers.

\section{Space Heating}

For his chairman's address to the Installations Section of the Institution of Electrical Engineers, R. Grierson took the subject of "British Climate and the Space-Heating Engineer" $(J$. Inst. Elec. Eng., 90, Pt. I, No. 29; May 1943) in which the means of assessing the thermal performance of space-heating installations on a rational basis rather than on the present empirical one are indicated. The address first reviews the basic factors involved in space-heating problems, then proceeds to discuss the internal temperatures required for maintaining the desired standard of thermal comfort, external temperatures, and temperature difference and degreedays. The address is printed in abstract in the Journal, but the complete text may be referred to in the Institution Library.

\section{Utilization of Small Coals}

THe British Coal Utilisation Research Association is arranging a conference on November 10 and 11 to discuss the problems related to the utilization of small coals with particular reference to the results obtained by the users of these fuels. It is known that a great body of valuable experience on the subject exists, and it is hoped, by means of the Conference, to make this experience available to those concerned, and by discussion to direct attention to the most practical and effective methods of utilization. The Conference has the full support and approval of the Fuel Efficiency Committee. There will be three sessions: November 10, at 2.30, on utilization of small coals and slurries; November 11, at 10, on utilization of fuels of high inert content; November 11 , at 2.30, on the upgrading of fuels. Offers of papers for discussion at the Conference should be sent to the Conference Secretary, B.C.U.R.A., Rickett Street, West Brompton, London, S.W.6. The Conference will be open without charge to all interested, by tickets obtainable from the Conference Secretary. Papers will be circulated in advance and the proceed. ings confined to a discussion of the papers.

\section{Searle's "Experimental Optics"}

Dr. G. F. C. Searle writes that additional accommodation for students attending the Cavendish Laboratory, Cambridge, has been obtained in the Geological Museum, and the task of transferring the opties class to that Museum has begun. Dr. Searle's "Experimental Optics", which is required for the course contemplated, is out of print, and Dr. Searle asks former pupils to offer copies of this book which they may have retained to the Laboratory. Letters should be sent to Dr. Searle before sending the books; the Laboratory will pay $16 s$. for each copy in fair condition.

\section{Colonial Service Appointments}

THE following appointments have recently been made in the Colonial Service: J. F. G. Wheeler to be marine biologist, Mauritius; J. C. Eyre, agricultural officer, Tanganyika Territory, to be senior agricultural officer, Palestine; J. Smith, assistant conservator of forests, Nigeria, to be senior assistant conservator of forests, Nigeria; J. E. Taylor, assistant conservator of forests, Nigeria, to be senior assistant conservator of forests, Nigeria; R. C. Burgess, lands officer and senior surveyor, Sierra Leone, to be director of surveys and lands, Sierra Leone; W. Harrison, surveyor, Nigeria, to be senior surveyor, Gold Coast. 